\section{KẾT LUÂ̂N}

Đặc điểm lâm sàng, cận lâm sàng của bệnh nhân có hội chứng cai rượu nặng:

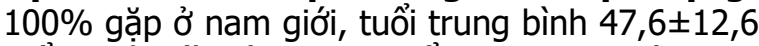
tuổi, chủ yếu từ 40-60 tuổi $(68,4 \%)$, thời gian nghiện rươu $18,7 \pm 8,55$ năm; tỉ lệ uống 500 $700 \mathrm{ml} / \mathrm{ngày}$ cao $(63,2 \%)$; hội chứng cai kéo dài trung bình 3,8 ngày.

Đăc điểm lâm sàng: Bệnh nhân có đầy đủ các dấu hiệu nặng theo thang điểm CIWA-Ar: dấu hiệu run (100\%), lo âu (100\%), vã mồ hôi $(97,4 \%)$, kích động $(92,1 \%)$, buồn nôn và nôn $(28,9 \%)$, đau đầu ít gặp nhất $(15,8 \%)$. Các rối loạn ảo giác: thính giác $(92,1 \%)$, thị giác $(89,5 \%)$, xúc giác $(23,7 \%)$. Rối loạn định hướng gặp ở 76,3\% bệnh nhân. Biến chứng viêm phổi $(39,5 \%)$ và $15,8 \%$ số phải thở máy. Cận lâm sàng: tăng lactat máu, lactat trung bình $3,2 \pm 1,44 \mathrm{mmol} / \mathrm{l}$, tăng CK, AST, ALT; cải thiện tốt khi bệnh nhân ra viện $(p<0,01)$.

\section{TÀI LIÊU THAM KHẢO}

1. Bộ Y Tế (2014). Báo cáo chung tổng quan ngành $Y$ tế năm 2014: Tăng cường dự phòng và kiểm soát bệnh không lây nhiễm. Nhà xuất bản Y học, 52

2. Deepali Dixit, Jeffrey Endicott, Lisa Burry et al (2016). Management of Acute Alcohol Withdrawal Syndrome in Critically Ill Patients. Pharmacotherapy: The Journal of Human Pharmacology and Drug Therapy, 36(7), 797-822.

3. Sarff M. and J. A. Gold (2010). Alcohol withdrawal syndromes in the intensive care unit. Crit Care Med, 38(9 Suppl), S494-501.

4. American Psychiatric Association (2013). Diagnostic and statistical manual of mental disorders $5^{\text {th }}$ (DSM-5®), American Psychiatric Pub. 2013.

5. Carol A Puz, Stokes SJ (2005). "Alcohol withdrawal syndrome: assessment and treatment with the use of the Clinical Institute Withdrawal Assessment for Alcohol-revised". Crit Care Nurs Clin North Am. 17 (3): 297-304.

6. Phan Văn Tiếng, Phạm Công Hòa, Nguyễn Văn Bảy (2011). Nhân xét kết quả điếu trị sảng rượu bằng diazepam tại Bệnh viện Tâm thần Trung ương 2.

7. Ngô Chí Hiếu, Nguyễn Thị Dụ (2003). Nghiên cứu đặc điểm lâm sàng, cận lâm sàng và hồi sức bênh nhhân có hôi chứng cai rượu. Luận văn thạc sî Trường Đại học Y Hà Nội.

8. Jesse S., G. Bråthen, M. Ferrara et al (2017). Alcohol withdrawal syndrome: mechanisms, manifestations, and management. Acta Neurologica Scandinavica, 135(1), 4-16.

\title{
THỰC HÀNH PHÒNG CHỐNG TĂNG HUYẾT ÁP VÀ MỘT SỐ YẾU TỐ LIÊN QUAN Ở ĐỒNG BÀO CHĂM KHU VỰC NAM TRUNG Bộ
}

\section{TÓM TẮT}

Xác định tỷ lệ thực hành đúng về phòng chống tăng huyểt áp và một số yếu tố liên quan ở đồng bào Chăm khu vực Nam Trung Bộ. Thiết kế cắt ngang mô tả được tiến hành trên 5.482 đồng bào Chăm từ 18 tuổi trở lên sinh sống tai 11 xã thuốc 4 tỉnh Ninh Thuận, Bình Thuận, Bình Định và Phú Yên từ tháng $10 / 2016$ đến tháng 10/2017. Kết quả cho thấy, tỷ lệ đồng bào Chăm có thực hành chung đúng về phòng chống tăng huyết áp còn thấp 23,6\%. Trong đó, tỷ lệ đồng bào Chăm không lam dụng rượu bia là 89,9\%, ăn ît mõ là $84,1 \%$, khống hút thuốc lá là $81,8 \%$, không ăn mặn là $52,7 \%$, có hoạt động thể lực là $67,2 \%$ và ăn đủ rau quả là $37,5 \%$. Mồt số yếu tố liên quan đến thực hành phòng chống tăng huyết áp đặc trưng ở đồng bào dân tộc Chăm được tìm thây gồm

${ }^{1}$ Bênh viện Quân Y 175

2Trường Đại họ Trà Vinh

${ }^{3}$ Viện Pasteur thành phố Hồ Chí Minh

Chịu trách nhiệm chính: Nguyễn Ngọc Huy

Email: huydr175@gmail.com

Ngày nhân bài: 25.01.2021

Ngày phản biên khoa hoc: 16.3.2021

Ngày duyệt bài: 23.3.2021
Nguyễn Ngọc Huy ${ }^{1}$, Nguyễn Văn Tập ${ }^{2}$, Trần Phúc Hậu ${ }^{3}$, Nguyễn Thanh Bình ${ }^{2}$

nhóm tuổi, trình độ học vấn, nghề nghiệp, tình trạng hôn nhân và kiến thức về phòng chống tăng huyết áp $(p<0,05)$. Cần có các can thiệp về phòng chống các yếu tố nguy cơ của tăng huyết áp cho đồng bào Chăm.

Tư khóa: Thực hành, tăng huyết áp, đồng bào dân tộc Chăm, Nam Trung Bộ

\section{SUMMARY \\ PRACTICE AND SOME FACTORS RELATED TO HYPERTENSION PREVENTION IN THE CHAM ETHNIC MINORITY IN THE SOUTH- CENTRAL REGION}

The study aimed to describe the good practices and some related factors to hypertension prevention in Cham ethnic minority 18 years of age or older in the South-Central Region. A cross-sectional study was conducted on 5.482 Cham people 18 years of age or older at 11 communes in Ninh Thuan, Binh Thuan, Binh Dinh and Phu Yen provinces from October 2016 to October 2017. The results showed that the prevalence of good practices on hypertension prevention in Cham minority group was low (23.6\%). In which, good practices on hypertension prevention with not abusing alcohol (89.9\%), less eating fat $(84.1 \%)$, not smoking $(81.8 \%)$, physical activity $(67.2 \%)$, not eating salty food $(52.7 \%)$, and eating 
enough vegetable and fruit diet (37.5\%). Some factors related to practices on hypertension prevention in Cham ethnic minority group found in the study included age group, education level, occupational, marital status, and knowledge on hypertension prevention $(p<0.05)$. The results highlighted the need for interventions for hypertension behavioral risk factor prevention among the Cham population.

Keywords: Practice, hypertension, Cham ethnic minority, South-Central Region

\section{I. ĐĂT VẤN ĐỀ}

Tăng huyết áp là bệnh không lây nhiễm, tỷ lệ mắc ngày càng gia tăng trong cộng đồng. Theo báo cáo của Tổ chức Y tế thế giới năm 2014, tỷ lệ chung trên toàn thế giới là $22 \%$, có xu hướng tăng ở các nước đang phát triển. Theo dự đoán, số mắc tăng huyết áp sẽ tăng lên 1,56 tỷ người vào năm 2025. Tỷ lệ hiện mắc của tăng huyêt áp ở người trưởng thành khoảng $30 \%-45 \%$. Mặc dù đã có nhiều chiến lược điều trị thuốc và thay đổi lối sống tỏ ra hiệu quả, tuy nhiên tỷ lệ kiểm soát huyết áp trên thế giới vẫn chưa cao. Tại Việt Nam, theo báo cáo của Hội tim mạch Việt Nam (2016), tỷ lệ tăng huyết áp ở người trưởng thành là 47,3\%. Trong số những người được xác định có tăng huyết áp có tới $39,1 \%$ khồng hề biết mình mắc tăng huyết áp, 60,9\% những người được phát hiện có $7,2 \%$ không được điều trị [7]. Nhiều nghiên cứu đã chỉ ra lối sống, thói quen ăn uống, hoạt động thể lực, lạm dụng rượu bia và hút thuốc lá tác động tới tăng huyết áp. Phần lớn những yếu tố nguy cơ này có thể kiểm soát được khi hiểu biết đúng và biết được cách phòng tránh. Tuy có rất nhiều nghiên cứu về tăng huyết áp nhưng phần lớn tập trung nghiên cứu ở người Kinh. Nghiên cứu về hành vi phòng chống tăng huyết áp ở dân tộc thiểu số còn hạn chế. Đồng bào Chăm là một trong 53 dân tộc ít người ở Việt Nam, với số lượng khoảng 167.128 người sinh sống chủ yếu ở khu vực Nam Trung Bộ [6]. Đồng bào Chăm có những nét văn hóa riêng, có nhiều phong tục tập quán, trong đó còn có những tập quán khồng tốt cho sức khỏe ảnh hưởng đến tăng huyết áp. Vì vậy, chúng tôi thực hiện nghiên cứu "Thực hành về phòng chông tăng huyêt áp và một số yêu tố liên quan ở đồng bào dân tộc Chăm tại khu vực Nam Trung Bộ".

\section{II. ĐỐI TƯỢNG VÀ PHƯƠNG PHÁP NGHIÊN CỨU}

2.1 Đồi tượng nghiên cứu. Đồng bào Chăm từ 18 tuổi trở lên sinh sống tại 11 xã thuộc 4 tỉnh Ninh Thuận, Bình Thuận, Bình Định và Phú Yên.
2.2 Địa điểm và thời gian nghiên cứu. Nghiên cứu được thực hiện tại 11 xã thuộc 4 tỉnh Ninh Thuận, Bình Thuận, Bình Định và Phú Yên từ tháng 10/2016 đến tháng 10/2017.

2.3 Thiết kế nghiên cứu. Nghiên cứu mô tả cắt ngang

2.4 Cỡ mẫu. Cỡ mẫu tính theo công thức ước lượng một tỷ lệ, cõ̃ mẫu n.

$$
\mathrm{n}=\mathrm{Z}^{2} 1-\mathrm{a} / 2 \frac{\mathrm{p} \times(1-\mathrm{p})}{\mathrm{d}^{2}} \times \mathrm{DE}
$$

Trong đó: $Z^{2}{ }_{1-\alpha / 2}$ độ tin cậy, với độ tin cậy $95 \% ; Z^{2}{ }_{1-\alpha / 2}=(1,96)^{2}=3,84 ; \mathrm{p}$ : trị số mong muốn của tỷ lệ. Theo thống kê của Tố chức $Y$ tế thế giới (2014), tỷ lệ tăng huyết áp của người Việt Nam là $22 \%$. Chọn $p=0,22 ; d=0,05$ : là sai số lựa chọn; $\mathrm{DE}=1,5$ : Hệ số thiết kế.

Để đảm bảo độ tin cậy cho kết quả điều tra, căn cứ vào nguồn lực cụ thể và đặc điểm dân số, sự phân bố dân số chung cũng như nhóm dân số đồng bào dân tộc Chăm trong khu vực Nam Trung Bộ. Tỷ lệ đồng ý tham gia nghiển cứu ước tính là $80 \%$; Số xã tiến hành nghiên cứu: 11 xã. Tính cõ̃ mẫu tối thiểu là $\mathrm{n}=5.445$ người. Thực tế chúng tôi chọn được 5.482 người tham gia nghiên cứu.

2.5 Phương pháp chon mẫu. Áp dụng phương pháp chọn mẫu ngấu nhiên 2 giai đoạn gồm chọn cụm và chọn đối tượng điều tra.

Bước 1: Chọn cự: Mỗi cựm là 1 thôn. Chọn chủ đích 11 xã có đông đào bào Chăm sinh sống. Tai mỗi xã được chọn, bốc thăm ngẫu nhiên mỗi xã là 3 thôn.

Bước 2: Chọn đối tượng nghiên cứu: Tại mỗi cựm được chọn, lập danh sách đồng bào Chăm từ 18 tuổi trở lên. Áp dụng phương pháp chọn mẫu ngẫu nhiên hệ thống trên danh sách đồng bào Chăm đã được lập để chọn ra đủ số lượng đối tượng nghiên cứu.

\subsection{Biến số nghiên cứu:}

Ăn mặn: ăn những thức ăn mă̆n $\geq 3$ ngày/tuân hoặc sử dụng lượng muối mối ngày $\geq$ 5 gam bình quân cho mối người trong gia [7].

Lam dụng rượu/bia: khi uống $\geq 5$ ly chuẩn/lần đối với nam và uống $\geq 4$ ly chuẩn/lần đối với nữ [7].

Hoạt động thể lực: Có khi tập thể dục hay vận động thể lực $\geq 30$ phút/ ngày [8].

Ăn nhiều mõ động vật: ăn mõ thường xuyên trên $25 \%$ lipid/ngày và trên $7 \%$ mõ bảo hòa hay trên 300 gam/người/tháng, thường xuyên ăn mõ động vật, chất béo trên 4 ngày/tuần. Ước lượng theo bàn tay Zimbabwe lượng mõ ăn vào trong một bữa ăn nhiều hơn một lượng bằng đầu ngón tay cái [7]. 
Ăn đủ lượng rau quả, chất xơ: Có khi lượng rau hoặc quả ăn trung bình mỗi ngày $\geq 5$ suất. Mỗi suất rau quả tương đương với 80gam. Ước lượng theo bàn tay Zimbabwe mỗi bữa ăn lượng rau cần hơn 2 bàn tay [7].

Thực hành chung đúng phòng chống tăng huyết áp: khi thực hiện đúng cả 6 nội dung gồm không hút thuốc lá, không lạm dụng rượu bia, không ăn mặn, không ăn nhiều mỡ, ăn đủ rau quả và có hoạt động thể lực.

2.7 Phương pháp thu thập thông tin. Tất cả đối tượng nghiên cứu được thông tin về nghiên cứu và được mời đến trạm y tế xã/phường để tham gia đợt khám sức khỏe miễn phí. Đối tượng được đo lường các chỉ số huyết áp, chiều cao, cân nặng. Tiếp đến, đối tượng nghiên cứu được khám, hỏi bệnh và được phỏng vấn về đặc điểm nhân khẩu học, các hành vi nguy cơ.

2.8 Phương pháp xử lý số liệu. Số liệu được nhập bằng Epidata 3.0, được làm sạch và phẩn tích bằng phần mềm Stata/IC14.0. Kết quả trình bày theo dạng bảng tần số, tỷ lệ. Sử dụng test $\chi^{2}$ để so sánh các tỷ lệ. Sử dụng mô hình hồi quy đa biến Logistic để kiểm soát tác động của các biến số gây nhiễu và tương tác khi xét mối liên quan giữa biến số phụ thuộc và các biến số độc lập.

2.9 Đạo đức nghiên cứu. Nghiên cứu nhận được sự chấp thuận của Viện Pasteur thành phố Hồ Chí Minh, được sự cho phép của Sở $Y$ tế tỉnh Ninh Thuận, Sở $Y$ tế tỉnh Bình Thuận, Sở Y tế tỉnh Bình Định, Sở $Y$ tế tỉnh Phú Yên. Đối tượng nghiên cứu được cung cấp thông tin đầy đủ và lấy ý kiến đồng thuận trước khi tham gia, được bảo mật thông tin cá nhân và đảm bảo các quyền lợi khác.

\section{KẾT QUẢ NGHIÊN CỨU}

3.1 Thực hành phòng chống tăng huyết áp ở đồng bào Chăm khu vực Nam Trung Bộ

Bảng 1. Thực hành phòng chống tăng huyêt áp ở đồng bào Chăm khu vức Nam Trung Bô

\begin{tabular}{|c|c|c|c|}
\hline \multicolumn{2}{|c|}{ Nội dung thực hành } & \multirow{2}{*}{$\begin{array}{c}\begin{array}{c}\text { Số } \\
\text { lượng }\end{array} \\
4.487 \\
\end{array}$} & \multirow{2}{*}{$\begin{array}{l}\begin{array}{c}\text { Tỷ lệ } \\
\text { (\%) }\end{array} \\
81,8 \\
\end{array}$} \\
\hline Hiên đang hút & Không & & \\
\hline thuốc lá & Có & 995 & 18,2 \\
\hline \multirow{2}{*}{$\begin{array}{l}\text { Lạm dụng } \\
\text { rượu bia }\end{array}$} & Không & 4.928 & 89,9 \\
\hline & Có & 554 & 10,1 \\
\hline \multirow{2}{*}{$\begin{array}{c}\text { Chế độ ăn } \\
\text { mặn }\end{array}$} & Không & 2.887 & 52,7 \\
\hline & Có & 2.595 & 47,3 \\
\hline \multirow{2}{*}{$\begin{array}{l}\text { Chế độ ăn } \\
\text { chất béo }\end{array}$} & Ān ít mõ & 4.612 & 84,1 \\
\hline & Àn nhiều mõ̃ & 870 & 15,9 \\
\hline \multirow{2}{*}{$\begin{array}{l}\text { Chế độ ăn } \\
\text { rau quả }\end{array}$} & Àn đủ rau quả & 2.058 & 37,5 \\
\hline & Ann ít rau quả & 3.424 & 62,5 \\
\hline \multirow{2}{*}{$\begin{array}{c}\text { Hoạt động } \\
\text { thể lực }\end{array}$} & Có & 3.681 & 67,2 \\
\hline & Không & 1.801 & 32,8 \\
\hline \multirow{2}{*}{$\begin{array}{l}\text { Thực hành } \\
\text { chung }\end{array}$} & Đúng & 1.295 & 23,6 \\
\hline & Chưa đúng & 4.187 & 76,4 \\
\hline
\end{tabular}

Tỷ lệ đồng bào Chăm có thực hành chung đúng về phòng chống tăng huyết áp là $23,6 \%$. Trong đó, tỷ lệ đồng bào Chăm không lạm dụng rượu bia là $89,9 \%$, ăn ít mõ là $84,1 \%$, không hút thuốc lá là $81,8 \%$, không ăn mặn là $52,7 \%$, có hoạt động thể lực là $67,2 \%$ và ăn đủ rau quả là $37,5 \%$.

3.2 Một số yếu tố liên quan đến thực hành phòng chống tăng huyết áp ở đồng bào Chăm khu vực Nam Trung Bộ

Bảng 2. Phân tích đơn biến một số đặc điểm dân số xã hội liên quan đến thực hành phòng chống tăng huyết áp ở đồng bào Chăm khu vực Nam Trung Bộ

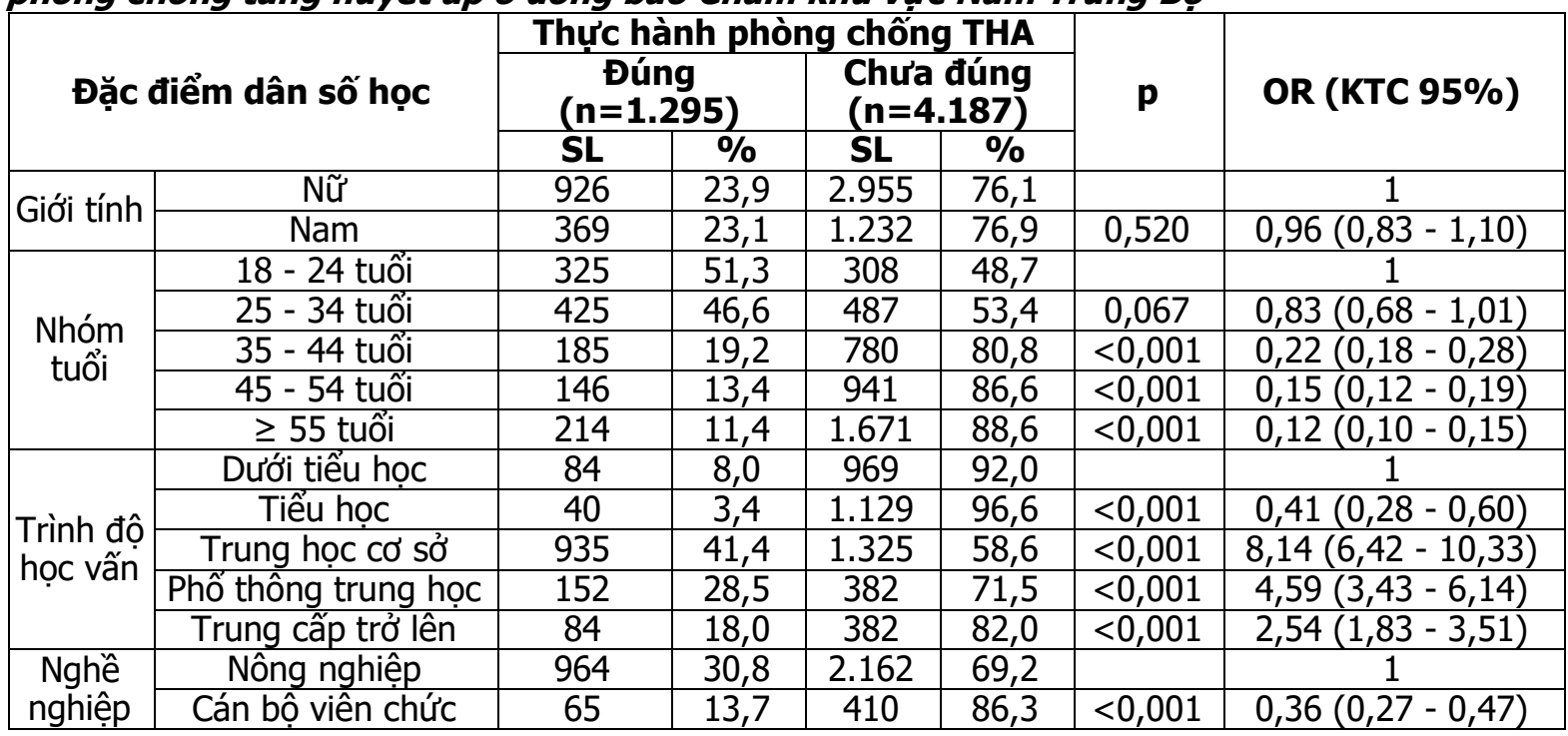


VIETNAM MEDICAL JOURNAL N01 - APRIL - 2021

\begin{tabular}{|c|c|c|c|c|c|c|c|}
\hline & Buôn bán & 34 & 15,5 & 186 & 84,5 & $<0,001$ & $0,41(0,28-0,60)$ \\
\hline & Nội trợ & 110 & 11,1 & 881 & 88,9 & $<0,001$ & $0,28(0,23-0,35)$ \\
\hline & Công nhân & 97 & 19,6 & 397 & 80,4 & $<0,001$ & $0,55(0,43-0,69)$ \\
\hline & Khác & 25 & 14,2 & 151 & 85,8 & $<0,001$ & $0,37(0,24-0,57)$ \\
\hline \multirow{3}{*}{$\begin{array}{c}\text { Tình } \\
\text { trạng } \\
\text { kinh tế }\end{array}$} & Nghèo/ cân nghèo & 417 & 25,4 & 1.225 & 74,6 & & 1 \\
\hline & Trung bình & 786 & 25,0 & 2.360 & 75,0 & 0,755 & $0,98(0,85-1,12)$ \\
\hline & Khá giả & 92 & 13,3 & 602 & 86,7 & $<0,001$ & $0,45(0,35-0,57)$ \\
\hline \multirow{3}{*}{\begin{tabular}{|c|} 
Tình \\
trạng \\
hôn nhân
\end{tabular}} & Chưa lập gia đình & 175 & 22,4 & 608 & 77,6 & & 1 \\
\hline & Sống cùng vợ/ chông & 1.078 & 26,7 & 2.967 & 73,3 & 0,012 & $1,26(1,05-1,51)$ \\
\hline & Góa/Ly thân/Ly dị & 42 & 6,4 & 612 & 93,6 & $<0,001$ & $0,24(0,17-0,34)$ \\
\hline \multirow{2}{*}{$\begin{array}{c}\text { Bảo hiếm } \\
\text { y tế }\end{array}$} & Có & 932 & 22,6 & 3.197 & 77,4 & & 1 \\
\hline & Không & 363 & 26,8 & 990 & 73,2 & 0,001 & $1,26(1,09-1.45)$ \\
\hline \multirow{2}{*}{ Béo phì } & Không & 1.123 & 24,8 & 3.412 & 75,2 & & 1 \\
\hline & Có & 172 & 18,2 & 775 & 81,8 & $<0,001$ & $0,67(0,56-0,81)$ \\
\hline \multirow{2}{*}{$\begin{array}{c}\text { Kiến thức } \\
\text { chung }\end{array}$} & Đúng & 680 & 42,8 & 907 & 51,2 & & 1 \\
\hline & Chưa đứng & 615 & 15,8 & 3.280 & 84,2 & $<0,001$ & $0,25(0,22-0,28)$ \\
\hline
\end{tabular}

Một số đă̆c điểm dân số liên quan đến thực hành phòng chống tăng huyết áp ở đồng bào Chăm $(p<0,05)$ : Nhóm tuổi, trình độ học vấn, nghề nghiệp, tình trạng kinh tế, tình trạng hôn nhân gia đình, bảo hiểm y tế, béo phì và kiến thức đúng chung về tăng huyết áp.

Bảng 3. Mô hình hồi quy đa biến một số yếu tố liên quan đến thực hành phòng chống tăng huyêt áp ở đồng bào Chăm khu vực Nam Trung Bộ

\begin{tabular}{|c|c|c|c|c|}
\hline \multicolumn{2}{|c|}{ Đặc điếm dân số học } & Phc & $\mathbf{O R}_{\mathrm{hc}}$ & KTC 95\% \\
\hline \multirow{5}{*}{ Nhóm tuổi } & $18-24$ tuối & & 1 & \\
\hline & $25-34$ tuối & $<0,001$ & 0,57 & $0,43-0,75$ \\
\hline & 35 - 44 tuối & $<0,001$ & 0,11 & $0,08-0,15$ \\
\hline & 45 - 54 tuối & $<0,001$ & 0,07 & $0,05-0,10$ \\
\hline & $\geq 55$ tuối & $<0,001$ & 0,08 & $0,06-0,11$ \\
\hline \multirow{5}{*}{$\begin{array}{l}\text { Trình độ } \\
\text { học vấn }\end{array}$} & Dưới tiếu học & & 1 & \\
\hline & Tiếu học & $<0,001$ & 0,28 & $0,18-0,42$ \\
\hline & Trung học cơ sở & $<0,001$ & 4,64 & $3,53-6,09$ \\
\hline & Phố thông trung học & $<0,001$ & 2,59 & $1,79-3,74$ \\
\hline & Trung cấp trở lên & 0,002 & 1,87 & $1,25-2,79$ \\
\hline \multirow{6}{*}{ Nghề nghiệp } & Nông nghiệp & & 1 & \\
\hline & Cán bộ viền chức & $<0,001$ & 0,29 & $0,20-0,42$ \\
\hline & Buôn bán & 0,567 & 0,88 & $0,56-1,37$ \\
\hline & Nội trợ & $<0,001$ & 0,33 & $0,25-0,42$ \\
\hline & Công nhân & $<0,001$ & 0,21 & $0,15-0,30$ \\
\hline & Khác & 0,005 & 0,48 & $0,29-0,80$ \\
\hline \multirow{3}{*}{$\begin{array}{l}\text { Tình trang } \\
\text { kinh tế }\end{array}$} & Nghèo/ cận nghèo & & & 1 \\
\hline & Trung bình & 0,882 & 1,02 & $0,81-1,28$ \\
\hline & Khá giả & 0,070 & 0,73 & $0,52-1,03$ \\
\hline \multirow{3}{*}{$\begin{array}{l}\text { Tình trang } \\
\text { hôn nhân }\end{array}$} & Chưa lập gia đình & & & 1 \\
\hline & Sống cùng vợ/ chồng & $<0,001$ & 1,91 & $1,44-2,53$ \\
\hline & Góa/Ly thân/Ly dị & 0,134 & 1,42 & $0,90-2,24$ \\
\hline \multirow{2}{*}{\multicolumn{2}{|c|}{$\frac{\text { Béo phì }}{\text { Không có báo hiếm y tế }}$}} & 0,917 & 1,01 & $0,81-1,26$ \\
\hline & & 0,567 & 1,07 & $0,85-1,36$ \\
\hline \multicolumn{2}{|c|}{ Kiến thức chưa đúng } & $<0,001$ & 0,24 & $0,21-0,28$ \\
\hline
\end{tabular}

Sau khi kiểm soát các yếu tố bằng mô hình đa biến, một số yếu tố liên quan đến thực hành phòng chống tăng huyết áp ở đồng bào Chăm $(p<0,05)$ : nhóm tuổi, trình độ học vấn, nghề nghiệp, tình trạng kinh tế, tình trạng hôn nhân, BMI và kiến thức phòng chống tăng huyết áp.

\section{BÀN LUÂ̂N}

4.1 Thực hành phòng chống tăng huyết áp ở đồng bào Chăm. Kết quả nghiên cứu của chúng tôi thấy, tỷ lệ đồng bào Chăm có thực hành chung đúng về phòng chống tăng huyết áp là $23,6 \%$. Kết quả này cao hơn kết quả nghiên cứu của Trần Văn Tân (2014) tại Bình Định, tỷ lệ người dân có thực hành đúng về tăng huyết áp 
là 19,2\% [4], tuy nhiên thấp hơn kết quả nghiên cứu của Nguyễn Thanh Bình (2015) tại Trà Vinh, đồng bào Khmer có thực hành chung đúng là $54,7 \%$ [1], có thể do cách tính điểm thực hành chung đúng khác nhau. Thực hành chung đúng phòng chống tăng huyết áp trong nghiên cứu của chúng tôi khi người dân thực hiện đúng 6 nội dung gồm không hút thuốc lá, không lạm dụng rượu bia, không ăn mặn, không ăn nhiều mõ̃, ăn đủ rau quả và có hoạt động thể lực. Trong nghiên cứu của tác giả Nguyễn Thanh Bình (2015) tại Trà Vinh, thực hành chung đúng khi người dân thực hiện đúng 3 nội dung không ăn nhiều mõ, không lạm dụng rượu bia và có hoạt động thể lực [1]. Bên canh đó, thực hành đúng còn phụ thuộc vào thói quen, phong tục tập quán cũng như khả năng tiếp cận kiến thức phòng ngừa tăng huyết áp.

Tỷ lệ đồng bào Chăm ăn rau quả cao hơn so với các nghiên cứu trước. Với khí hậu khu vực Nam Trung Bộ khắc nghiệt, nóng và gió, có tháng nhiệt độ lên đến $35^{\circ} \mathrm{C}$ đến $36^{\circ} \mathrm{C}$, đồng bào Chăm thường thích ăn rau để lấy lại sự thăng bằng thân nhiệt, giữ thân nhiêt được điều hòa để tránh bệnh tật. Đồng bào Chăm có nhiêu nét đặc trưng về vằn hoá, tần suất lễ hội diễn ra quanh năm. Vì vậy, tỷ lệ cao đồng bào Chăm có tình trạng lạm dụng rượu bia 10,1\%.

Bên cạnh đó, với vị trí địa lý giáp biển kèm theo lối sống đặc trưng khu vực Nam Trung Bộ, tỷ lệ đồng bào Chăm ăn mặn là $47,3 \%$. Tỷ lệ ăn mặn trên cộng đồng dân tộc $S^{\prime}$ tiêng tại Bình Phước là $60,8 \%$ [2] và trên đồng bào Nùng tại Thái Nguyên là 50,0\% [5]. Nhìn chung, tỷ lệ ăn mặn ở đồng bào dân tộc thiểu số khá cao. Chế độ ăn mặn phụ thuộc nhiều vào phong tục tập quán và vị trí địa lý, đồng bào Chăm rẩt chú trọng gia vị dù đớn giản như ớt, hành, sả, mắm muối trong chế biến món ăn. Gia vị làm cho món ăn đậm đà, hợp khẩu vị.

4.2 Một số yếu tố liên quan đến thực hành phòng chống tăng huyết áp ở đồng bào Chăm. Nhóm tuổi liên quan đến thực hành phòng chống tăng huyết áp: Nghiên cứu của chúng tôi cho thấy tỷ lệ thực hành đúng về phòng chống tăng huyết áp ở những người lớn tuổi thấp hơn so với nhóm tuổi từ 18 - 24 tuổi. Tương tự, nghiên cứu của Trần Văn Tân (2015) tại Bình Định, nhóm tuổi càng cao thì thực hành đúng càng thấp, nhóm tuổi từ 18 - 24 tuổi thì khả năng tiếp cận thông tin, kiến thức phòng bênh tật dẽ dàng hơn sao với nhóm tuổi khác [4]. Vì vậy, cần tập trung nâng cao kiến thức và thực hành phòng chống tăng huyết áp ở nhóm người lớn tuổi.
Trình độ học vấn liên quan đến thực hành phòng chống tăng huyết áp: Tỷ lệ thực hành đúng về phòng chống tăng huyết áp ở những người có trình độ học vấn từ trung học cơ sở trở lên cao hơn so với những người có trình độ học vấn dưới tiểu học. Tương tự, nghiên cứu của Trần Văn Tân (2015) tại Bình Định, những người có học vấn trên trung học có số chênh thực hành đúng bằng 2,8 lần so với những người học trung học $(p<0,05)$ [4]. Trình độ học vấn càng cao khả nằng tiếp thu kiến thức, thực hành phòng ngừa bệnh tật càng tốt, cũng như sự hiểu biết và quan tầm vẩn đề sức khoẻ bản thân nhiều hơn người có học vấn thấp.

Nghề nghiệp liên quan đến thực hành phòng chống tăng huyết áp: Tỷ lệ thực hành đúng về phòng chống tăng huyết áp ở cán bộ viên chức thấp hơn so với người làm nghề nông. Nhiều nghiên cứu về phía cạnh khác của bệnh tăng huyết áp ở cộng đồng cho thấy người lao động trí óc thường hay bận rộn, quan tâm công việc và kinh tế hơn người lao động chân tay, cũng như đặt thù công việc, nên họ ít có thời gian quan tầm đến sức khoẻ bản [3].

Tình trạng hôn nhân liên quan đến thực hành phòng chổng tăng huyết áp: Những người sống chung với vợ chồng có số chênh thực hành tăng huyết áp đúng bằng 1,91 lần so với người chưa lập gia đình. Một số nghiên cứu đã chỉ ra rằng việc kết hôn đêm lại sự hài lòng và hỗ trợ giữa vợ và chồng, các cặp vợ chồng thường kiểm soát hành vi sức khoẻ, quan tâm và chăm sóc lẫn nhau. Từ đó nhận thức được hành vi nguy cơ sức khoẻ cho bản thân dẫn đến giảm các hành vi sức khỏe nguy cơ, đặc biệt là uống rượu và hút thuốc, chế độ dinh dưỡng, tăng thực hành hành vi có lợi sức khoẻ cá nhân và gia đình [8]. Để nâng cao hành vi thực hành đúng phòng chống tăng huyết áp chúng ta cần quan tâm tới đối tượng độc thân nhiều hơn và có chiến lược can thiệp phù hợp trên đối tượng này.

Kiến thức liên quan đến thực hành phòng chống tăng huyết áp: Tỷ lệ thực hành đúng về phòng chống tăng huyết áp ở những người có kiến thức đúng cao hơn so với những người có kiến thức chưa đúng. Kết quả này cũng phù hợp với nghiên cứu của Trân Văn Tân (2015) tại Bình Định, những người có kiến thức đúng thì có số chênh thực hành đúng bằng 1,8 lần so với người có kiến thức chưa đúng $(p<0,05)[4]$. Nhìn chung, để nâng cao tỷ lệ thực hành đúng thì cần nâng cao kiến thức bảo vệ sức khoẻ cho người dân nói chung và kiến thức về tăng huyết áp nói riêng. 


\section{KẾT LUẬN}

Tỷ lê đồng bào Chăm có thực hành chung đúng vể phòng chống tăng huyểt áp còn thấp. Để góp phần hạn chế tỷ lệ tăng huyết áp ở đồng bào Chăm cần tăng cường công tác truyền thông, nâng cao kiến thức tạo điều kiện cho đồng bào Chăm tiếp cận thông tin y tế cần thiết.

\section{TÀI LIÊU THAM KHẢO}

1. Nguyễn Thanh Bình, Nguyễn Văn Tâp, Nguyến Văn Cường, Trần Vằn Hưởng (2016), "Thức trạng và một số yếu tố liên quan đến tăng huyết áp ở đồng bào dân tộc Khmer từ 25 đến 64 tuổi tại tỉnh Trà Vinh năm 2015". Tạp chí Y học dự phòng, Tâp 26, Số 13, tr.173-180.

2. Ngụy Văn Đôn, Đặng Đức Toàn, Văn Hữu Tài (2013), "Tỷy lế tăng huyết áp và môt số yếu tố liên quan ở người dẩn tộc S'tiêng trưởng thành taii xã Thiên Hưng, Bù Đốp, Bình Phước năm 2009". Tap chí $Y$ hoc Thức hành, 897, tr.79-82.

3. Bừi Thị Nhi (2015), Tỷ lệ tuân thủ điều tri và các yếu tố liên quan của bẹnh nhân tăng huyết áp tại xã Phước Lợi, huyện Bến Lức, tỉnh Long An năm
2015, Khóa luận tốt nghiệp cử nhân Y tế Công cộng, Trường Đại học Y Dược thành phố Hồ Chí Minh, tr.76.

4. Trân Văn Tân, Trương Quang Đạt (2015), "Kiến thức và thực hành về phòng chống tăng huyết áp của người dân ở các xã đảo của thành phố Quy Nhơn". Tạp chí Y học Dự phòng, Tập 25, Số 9, tr.128-133.

5. Chu Hồng Thẳng (2008), Nghiên cứu thực trang bệnh tăng huyêt ap và rối loạn chuyển hoá ỡ nguời tăng huyết áp tại xã Hoá Thượng, huyện Đồng Hỷ, tỉnh Thái Nguyên, Luận văn Thạc sĩ Y hooc, Đại học Y Dược Thái Nguyên, tr.54-73.

6. Ủy ban Dân tộc (2017), Tổng quan thực trang kinh tế - xã hội của 53 dân tộc thiểu số, Hà Nội, tr.98-99.

7. Nguyê̂n Lân Việt (2016), Kết quả mới nhất điều tra tăng huyết áp toàn quốc năm 2015 - 2016, Hội tim mach hoc Viêt Nam

8. Ali M.M., Ajilore O. (2011), "Can Marriage Reduce Risky Health Behavior for AfricanAmericans?". Journal of Family and Economic, 32, pp.191-203.

\section{PHÂN TÍCH TÌNH HÌNH SỬ DUUNG KHÁNG SINH TRONG ĐIỀU TRI NHIỄM KHUẨN GRAM ÂM ĐA KHÁNG TẠI BỆNH VIỆN ĐA KHOA ĐỒNG NAI}

\section{TÓM TẮT}

Mục tiêu: Phân tích tình hình đề kháng và sử dunng kháng sinh trong điều trị nhiếm khuẩn các vi khuẩn gram âm đa kháng, đánh giá sư hợp lý theo các khuyến cáo, khảo sát các yếu tố liên quan đến thất bai điều trị. Phương pháp nghiên cứu: hồi cứu, cắt ngang mô tả các xét nghiệm vi sinh, $\mathrm{KS} \bigoplus$ và hồ sơ bênh án dương tính với Acinetobacter baumannii hoặc Klebsiella pneumonia hoặc Pseudomonas aeruginosa tại ICU và khoa hô hấp bệnh viện Đồng Nai trong thời gian 01/01/2018 đến 31/12/2018. Kết quả: 301 HSBA được lựa chon. Có 32 kháng sinh trong 14 nhóm kháng sinh được lựa chon điêu tri nhiếm khuẩn: penicillin $96.6 \%$, carbapenem $58.5 \%$ và quinolon 30.9\%. Phối hợp 2 KS được ưu tiên sứ dung $(50.2 \%$ và $49.1 \%$ trước và sau khi có KSĐ), trong đó chủ yễu phối hợp quinolon và betalactam $33.2 \%$. Tî lệ KS phù hợp với KSĐ trước và sau khi có kết quả vi sinh $35.8 \%$ và $54.3 \%$. Hâuu hết phác đồ phù hợp với khuyến cáo điêuu trị $(65.6 \%)$. Tình trạng liên quan (thở máy và nhập ICU) làm tăng nguy cơ thất bại điêuu trị: thở máy $(\mathrm{OR}=5.2 ; 95 \%$

*Đại học Lạc Hồng, Đồng Nai

Chiu trách nhiêm chính: Đinh Thi Thúy Hà

Email: Dinhthuyha85@gmail.com

Ngày nhận bài: 20.01.2021

Ngày phản biên khoa học: 19.3.2021

Ngày duyệt bài: 23.3.2021
Đinh Thị Thúy Hà*

CI: $2.07 \div 13.07 ; \mathrm{P}<0.001)$, nhâp ICU (OR $=12.8$; 95\% CI: $4.61 \div 35.54 ; \mathrm{P}<0.001)$. Sử dụng kháng sinh nhạy cảm trên 7 ngày giúp giảm nguy cơ điêuu trị thất bại (OR $0.41 ; 95 \% \mathrm{CI}: 0.19 \div 0.89 ; \mathrm{P}=0.024$ ). Kết luân: Kháng sinh sử dung trong điêu trị nhiếm khuẩn gram âm đa kháng hầu hết phù hợp với các hướng dẫn điều trị. Thời gian dùng KS và tình trang liên quan (thở máy và nhập ICU) là các yếu tố liên quan kết quả điều trị.

Tư khóa: vi khuẩn gram âm đa kháng, acinetobacter, pseudomonas, klebsiella, kháng sinh

\section{SUMMARY \\ INVESTIGATION ON THE ANTIMICROBIAL THERAPY FOR TREATMENT OF INFECTIONS DUE TO MULTIDRUG- RESISTANT GRAM-NEGATIVE BACTERIA \\ AT DONG NAI GENERAL HOSPITAL}

Objectives: The aims of this study were to analyze the antibiotic resistance and the antibiotic used in treatment of multidrug-resistant gramnegative bacteria, to evaluate the appropriateness of antimicrobial therapy according to guidelines; and to identify risk factors contributing to treatment failures. Methods: We conducted a cross-sectional descriptive and retrospectively study. Results of susceptibility testing and medical records of patients with Acinetobacter baumannii or Klebsiella pneumonia or Pseudomonas aeruginosa infections at ICU and respiratory department of Dong Nai hospital from $1^{\text {st }}$ 